\title{
Activation of NF- $\kappa$ B by HDAC inhibitor apicidin through Sp1-dependent de novo protein synthesis: its implication for resistance to apoptosis
}

\author{
YK Kim ${ }^{\star, 1}$, EK Lee ${ }^{2}$, JK Kang ${ }^{2}$, JA Kim², J-S You'², JH Park², \\ D-W Seo ${ }^{3}$, JW Hwang ${ }^{1}$, S-N Kim ${ }^{4}$, HY Lee ${ }^{5}$, HW Lee ${ }^{2}$ and J-W Han ${ }^{*, 2}$ \\ ${ }^{1}$ College of Medicine, Kwandong University, Gangneung 210-701, Korea \\ ${ }^{2}$ College of Pharmacy, Sungkyunkwan University, Suwon 440-746, Korea \\ ${ }^{3}$ Department of Molecular Bloscience, Kangwon National University, \\ Chuncheon 200-701, Korea \\ ${ }^{4}$ KIST Gangneung Institute, Gangneung 210-340, Korea \\ ${ }^{5}$ College of Medicine, Konyang University, Nonsan 320-711, Korea \\ * Corresponding authors: YK Kim, Department of Pharmacology, Kwandong \\ University College of Medicine, 522 Naegok-dong, Gangneung, Gangwon-do \\ 210-701, Korea. Tel: + 8233649 7479; Fax: + 8233641 1074; \\ E-mail: yksnbk@ kwandong.ac.kr or J-W Han, Department of Biochemistry and \\ Molecular Biology, College of Pharmacy, Sungkyunkwan University, 300 \\ Cheoncheon-dong, Jangan-gu, Suwon, Gyeonggi-do 440-746, Korea. \\ Tel: + 8231290 7716; Fax: + 8231290 5403; \\ E-mail: jhhan551@ @kku.edu
}

Received 06.6.05; revised 02.2.06; accepted 23.2.06; published online 21.4.06 Edited by GM Cohen

\section{Abstract}

Histone deacetylase (HDAC) inhibitors are promising anticancer drugs, but these exert differential responses depending on the cell types. Here, we demonstrate a new mechanism for activation of nuclear factor- $\kappa B$ (NF- $\kappa B$ ) by HDAC inhibitor apicidin and the role of NF- $\kappa \mathrm{B}$ signaling pathway for mediating differential cellular responses, especially, apoptosis. Treatment of HeLa cells with apicidin increases transcriptional activity of NF- $\kappa$ B and its target gene IL-8 and clAP-1 induction, which involves the activation of IKK-IkB $\alpha$ signaling pathway through Sp1-dependent de novo protein synthesis. In parallel, apicidin treatment leads to histone hyperacetylation in the IL-8 promoter region independent of $\mathrm{NF}-\kappa \mathrm{B}$ signaling pathway, which is not sufficient for full transcription of IL- 8 gene. This NF- $\kappa$ B activation contributes to resistance of HeLa cells to apoptotic potential of apicidin. Collectively, our results suggest that activation of NF- $\kappa \mathrm{B}$ signaling cascade functions as a critical modulator to determine cell fate on apoptosis in response to HDAC inhibitors.

Cell Death and Differentiation (2006) 13, 2033-2041. doi:10.1038/sj.cdd.4401915; published online 21 April 2006

Keywords: NF- $\kappa$ B; HDAC inhibitor; apicidin; Sp1 transcription factor; apoptosis

Abbreviations: HDAC, histone deacetylase; HAT, histone

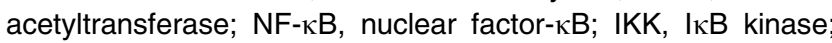
PDBu, phorbol-dibutyrate; ChIP, chromatin immunoprecipitation; SR-I $\mathrm{B} \alpha$, super repressor of I $\mathrm{K} \alpha$; GFP-p65, green fluorescent protein-p65 fusion protein; MTM, mithramycin; TSA, trichostatin A; NSCLC, non-small cell lung cancer

\section{Introduction}

Histone deacetylase (HDAC) inhibitors are emerging as a new class of anticancer agents for the treatment of solid and hematological malignancies. Treatment of tumor cells with HDAC inhibitors that accumulate acetylated histones in the nucleus, has been shown to induce transcriptional activation of critical genes needed for tumor growth arrest, differentiation, or apoptosis, depending on each cellular system. ${ }^{1-3}$ However, a global increase in the levels of histone acetylation in response to HDAC inhibitors cannot explain selective changes in gene expression; less than $2 \%$ of expressed genes was changed in cells treated with HDAC inhibitors. ${ }^{4,5}$ To address these selective changes in gene expression, some investigators have suggested that the transcriptional activation by HDAC inhibitors requires a mechanism other than chromatin remodeling through histone hyperacetylation, which is associated with protein kinase signaling pathways ${ }^{6-8}$ or acetylation of non-histone protein such as p53 or nuclear factor- $\kappa \mathrm{B}(\mathrm{NF}-\kappa \mathrm{B}) .{ }^{9,10}$ Recently, NF- $\kappa \mathrm{B}$ signaling pathway is appreciated as one of the pivotal modulators for determining specific gene expression and differential cellular responses by HDAC inhibitors. ${ }^{11}$

$\mathrm{NF}-\kappa \mathrm{B}$ is well known as a transcription factor that regulates the expression of a large number of genes in response to a variety of cellular conditions, including infection, inflammation, adhesion, cell cycle, and survival. ${ }^{12,13}$ Recent studies have established that NF- $\kappa$ B provides an antiapoptotic function in many different cancer cells, ${ }^{14}$ including non-small cell lung cancer (NSCLC) cells. ${ }^{11} \mathrm{NF}-\kappa \mathrm{B}$ has been thought to reside in the cytoplasm as an inactive form, bound by its inhibitory proteins, the $1 \kappa \mathrm{B}$ family, ${ }^{15,16}$ although NF- $\kappa \mathrm{B}$ may shuttle between the nucleus and cytoplasm in unstimulated cells. ${ }^{17,18}$ Stimulation of cells with specific inducers, such as cytokines, phorbol esters, and lipopolysaccharides activates the $I_{\kappa} \mathrm{B}$ kinase (IKK) complex, leading to phosphorylation of serines 32 and 36 of $\mathrm{I} \kappa \mathrm{B} \alpha$ or serines 19 and 23 of $\mathrm{I} \kappa \mathrm{B} \beta .^{19-22}$ This phosphorylation event triggers rapid ubiquitination and subsequent degradation of $\mathrm{I} \kappa \mathrm{B}$ proteins through the $26 \mathrm{~S}$ proteasome complex, thus allowing free NF- $\kappa$ B to translocate into the nucleus and resulting in transcriptional activation of its target genes. ${ }^{13,23}$

Interaction of NF- $\kappa \mathrm{B}$ with histone acetyltransferase (HAT) containing coactivators, including p300/CBP, the steroid recptor-coactivator-1, and the p300/CBP-associated factor, has been shown to activate transcription. ${ }^{24-29}$ Recently, it has been reported that acetylation of the NF- $\kappa$ B is responsible for sustaining NF- $\kappa$ B-dependent transcription ${ }^{10}$ and is regulated by HDAC family of proteins including HDAC-1, -2 , and -3 . $^{30-32}$ 
Therefore, NF- $\kappa \mathrm{B}$ target genes, which are essential for cell survival, could be regulated by acetylation of $\mathrm{NF}-\kappa \mathrm{B}$ and/or core histone proteins associated with promoter of target genes. In fact, acetylation of p65 subunit through inhibition of HDAC activity with trichostatin A (TSA) has been shown to potentiate the transcriptional activation of NF- $\kappa \mathrm{B}$ by $\mathrm{TNF} \alpha .{ }^{10}$ Furthermore, hyperacetylation of core histones associated with promoter of NF- $\kappa \mathrm{B}$ target gene IL-8 by TSA led to a further increase of TNF $\alpha$ induction of IL-8 gene transcription. ${ }^{30}$ However, in addition to the potentiation of TNF $\alpha$ action through direct acetylation of $\mathrm{NF}-\kappa \mathrm{B}$ and/or core histones in IL-8 promoter region, the existence of other mechanisms, such as activation of NF- $\kappa$ B signaling pathway, has been proposed; recent reports show that HDAC inhibitor alone treatment can induce the activation of $\mathrm{NF}-\kappa \mathrm{B}$ and its target gene expression. ${ }^{26,30}$ Therefore, it would be of great interest to elucidate the molecular mechanism governing NF- $\kappa \mathrm{B}$ activation by HDAC inhibitor alone and its cellular function. In this study, we report the first evidence that activation of $\mathrm{IKK}-\mathrm{I} \kappa \mathrm{B} \alpha$ signaling pathway is responsible for $\mathrm{NF}-\kappa \mathrm{B}$ activation by HDAC inhibitor, which is mediated by de novo protein synthesis through Sp1 transcription factor. Furthermore, this $\mathrm{NF}-\kappa \mathrm{B}$ activation contributes to unresponsiveness of $\mathrm{HeLa}$ cells to apicidin-induced apoptosis, implying the important role of $\mathrm{NF}-\kappa \mathrm{B}$ signaling pathway in differential cellular responses to HDAC inhibitors.

\section{Results}

\section{Activation of NF- $\kappa$ B by apicidin}

Recent studies, demonstrating that HDAC inhibitor TSA induced TNF $\alpha$-mediated NF- $\kappa$ B transcriptional activity, ${ }^{10,30}$ led us to investigate a molecular mechanism of NF- $\kappa \mathrm{B}$ mediated transcription in response to HDAC inhibitor apicidin. We first examined whether an HDAC inhibitor alone could stimulate the transcriptional activity of NF- $\kappa \mathrm{B}$ in HeLa cells, using apicidin or a structurally unrelated HDAC inhibitor TSA for various time points. As shown in Figure 1a, apicidin treatment causes the activation of NF- $\kappa$ B-mediated transcription in a time-dependent manner. Similarly, TSA is also able to upregulate the transcriptional activity of $\mathrm{NF}-\kappa \mathrm{B}$, indicating that the activation of NF- $\kappa \mathrm{B}$ by apicidin might be attributed to the inhibition of HDAC activity. However, NF- $\kappa$ B activation by apicidin requires a little longer time than that by an $\mathrm{NF}-\kappa \mathrm{B}$ inducer phorbol-dibutyrate (PDBu) or TNF $\alpha$ (Figure 1b), suggesting the existence of alternative mechanism to initiate $\mathrm{NF}-\kappa \mathrm{B}$ activation by apicidin, and this mechanism is dependent on inhibition of HDAC activity.

\section{Involvement of IKK signaling pathway in transcriptional activation of NF- $\kappa$ B by apicidin}

In order to examine whether the activation of $\mathrm{NF}-\kappa \mathrm{B}$ reporter gene by apicidin was due to activation of transcription factor p65 via IKK signaling pathway, we transfected HeLa cells with either p65 subunit of NF- $\kappa \mathrm{B}$ complex or $\mathrm{I}_{\kappa} \mathrm{B} \alpha$. Figure 2 a shows that overexpression of p65 subunit increases the basal transcriptional activity of NF- $\kappa \mathrm{B}$, and that apicidin treatment dramatically increases the transcriptional activity of $\mathrm{NF}-\kappa \mathrm{B}$.
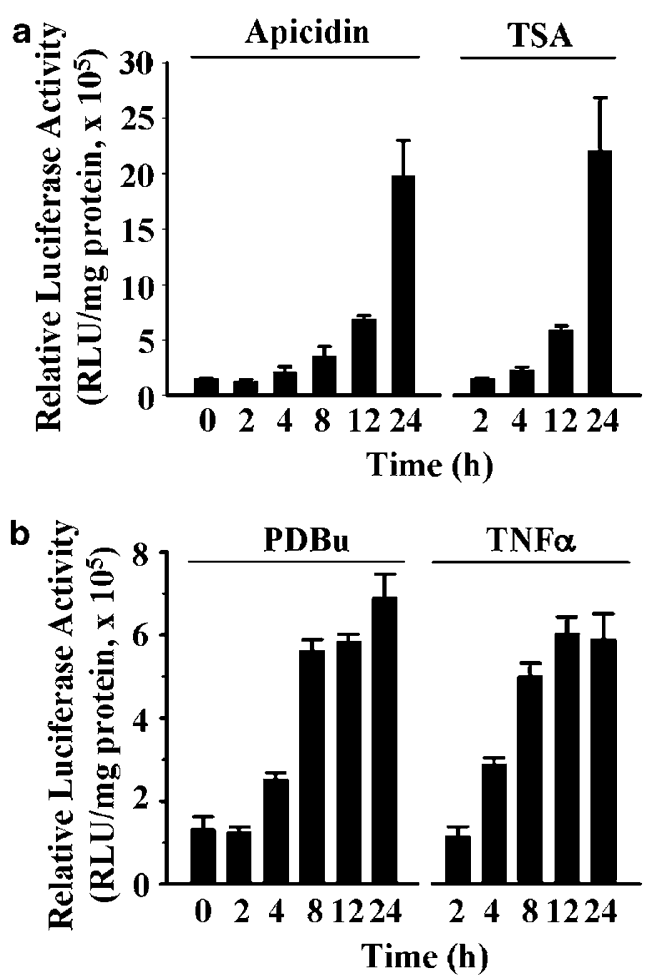

Figure $1 \mathrm{NF}-\kappa \mathrm{B}$-dependent reporter gene is activated by apicidin. HeLa cells were transfected with the NF- $\kappa$ B luciferase reporter plasmid DNA $(1 \mu \mathrm{g})$ for $24 \mathrm{~h}$, and further incubated for the indicated times with $1 \mu \mathrm{M}$ apicidin, $0.5 \mu \mathrm{M}$ TSA (a) $50 \mathrm{nM} \mathrm{PDBu}$, or $10 \mathrm{ng} / \mathrm{ml} \mathrm{TNF} \alpha$ (b). Luciferase activity was determined and normalized to the protein content of each extract as described in 'Materials and Methods'. Results from three independent transfections are presented as relative luciferase unit (RLU) per mg protein

On the other hand, overexpression of $\mathrm{I}_{\kappa} \mathrm{B} \alpha$ leads to a reduction of apicidin-induced expression of $\mathrm{NF}-\kappa \mathrm{B}$ reporter gene as well as the basal activity (Figure 2a), strongly suggesting that apicidin-induced activation of $\mathrm{NF}-\kappa \mathrm{B}$ is dependent on NF- $\kappa \mathrm{B}$ signaling pathway. To further confirm these observations, HeLa cells were also transfected with super repressor of $\mathrm{I}_{\kappa} \mathrm{B} \alpha\left(\mathrm{SR}-\mathrm{I}_{\kappa} \mathrm{B} \alpha\right)$ in which the serines at positions 32 and 36 had been changed to alanines. This protein blocks the activation of $\mathrm{NF}-\kappa \mathrm{B}$, because it can no longer be phosphorylated and degraded by $26 \mathrm{~S}$ proteasome. As expected, overexpression of $\mathrm{SR}-\mathrm{I}_{\kappa} \mathrm{B} \alpha$ completely inhibits both basal and apicidin-induced expression of $\mathrm{NF}-\kappa \mathrm{B}$ reporter gene (Figure 2a).

The phosphorylation of $\mathrm{I} \kappa \mathrm{B} \alpha$ responsible for NF- $\kappa \mathrm{B}$ activation is catalyzed by IKK complex, which consists of two catalytic subunits, $\mathrm{IKK} \alpha$ and $\mathrm{IKK} \beta$, and a regulatory subunit, $\mathrm{IKK} \gamma{ }^{22,33}$ The phosphorylation-induced degradation of $\mathrm{I}_{\kappa} \mathrm{Bs}$ is dependent on the $\mathrm{IKK} \beta$ subunit, whereas the $\mathrm{IKK} \alpha$ subunit does not make an essential contribution to this process. ${ }^{34,35}$ $\mathrm{We}$, therefore, determine which IKKs are involved in $\mathrm{NF}-\kappa \mathrm{B}$ activation in response to apicidin. Overexpression of dominant-negative mutant of $\mathrm{IKK} \beta$ inhibits the apicidin-induced expression of $\mathrm{NF}-\kappa \mathrm{B}$ reporter gene up to $70 \%$, whereas dominant-negative IKK $\alpha$ reduces only $20 \%$ of the transcriptional activity (Figure $2 b$ ), indicating that NF- $\kappa$ B activation by apicidin might adopt the canonical NF- $\kappa \mathrm{B}$ activation pathway. 

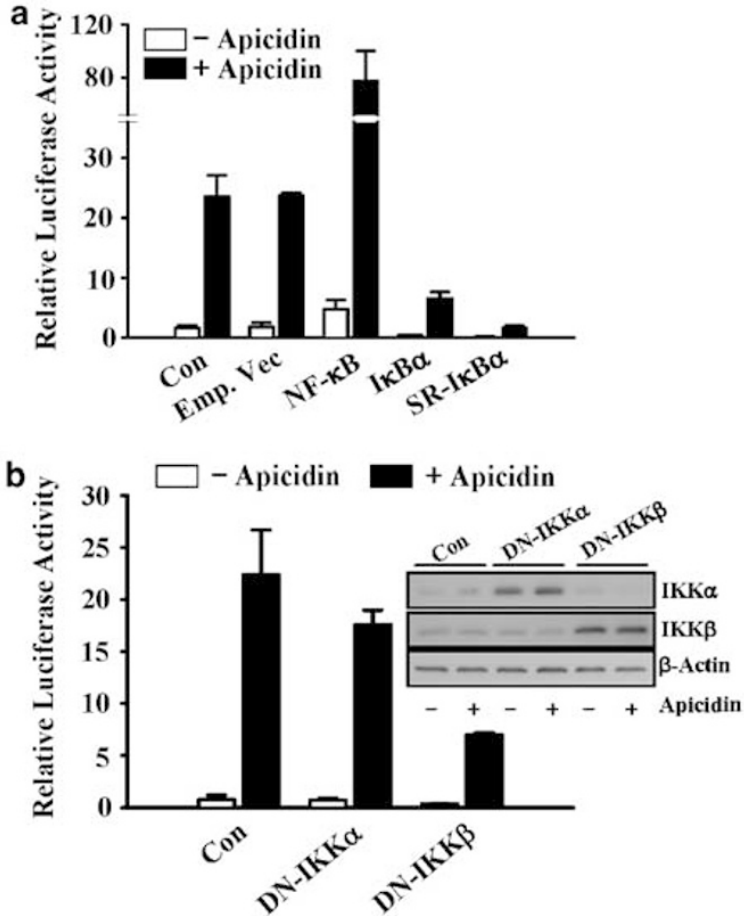

Figure 2 Apicidin-induced activation of NF- $\kappa \mathrm{B}$ reporter gene is dependent on $\mathrm{IKK}-\mathrm{I}_{\kappa} \mathrm{B} \alpha$ signaling pathway. HeLa cells were cotransfected with NF- $\kappa \mathrm{B}$ reporter plasmid DNA together with either wild-type NF- $\kappa$ B, wild-type $\left.\right|_{\kappa} \mathrm{B} \alpha$, SR-I $\mathrm{I}_{\mathrm{B}} \alpha$, or empty vector (a); and dominant-negative (DN) forms of IKK $\alpha$ or IKK $\beta(\mathbf{b})$. After $24 \mathrm{~h}$ of transfection, cells were incubated with $1 \mu \mathrm{M}$ apicidin for an additional $24 \mathrm{~h}$. Luciferase activity was determined as described in 'Materials and Methods'. Activity is expressed as fold increase relative to the untreated control

\section{Nuclear translocation of NF- $\kappa \mathrm{B}$ by apicidin}

To monitor potential effects of apicidin on the intracellular trafficking of $p 65$, we expressed green fluorescent protein-p65 fusion protein (GFP-p65) in HeLa cells. GFP-p65 expression is observed in the cytoplasmic compartment at $48 \mathrm{~h}$ after transfection and is sustained for $72 \mathrm{~h}$ (data not shown). Nuclear translocation of $\mathrm{p} 65$ by apicidin is not detectable at $4 \mathrm{~h}$; however, it gradually increases from later than $8 \mathrm{~h}$ until the end of these experiments: $52 \pm 4 \%$ at $8 h$ and $93 \pm 3 \%$ at $24 \mathrm{~h}$ (Figure 3a). However, the effect of apicidin does not appear to have occurred as a consequence of increased expression of nuclear GFP-p65, because apicidin treatment did not change the expression level of GFP-p65 protein (data not shown). Furthermore, overexpression of $\mathrm{SR}-\mathrm{I}_{\kappa} \mathrm{B} \alpha$ strongly blocks the apicidin-induced nuclear translocation of p65 $(92 \pm 3 \%$ (apicidin) versus $4 \pm 2 \%$ (SR-I $\kappa \mathrm{B} \alpha$ overexpression plus apicidin)) (Figure $3 b$ ). Consistent with these observations, pretreatment of HeLa cells with a proteasome inhibitor MG132 completely inhibits the nuclear translocation of p65 by apicidin (data not shown). To ascertain the effect of apicidin on the nuclear translocation of GFP-p65 ectopically overexpressed in HeLa cells, we directly examine the nuclear translocation of endogenous p 65 by apicidin treatment. As expected, the increased nuclear translocation of endogenous p65 is observed after treatment with apicidin for at least $8 \mathrm{~h}$, which is accompanied by an activation of IKK $\beta$ activity (Figure $3 \mathrm{~d}$ ) and subsequent decrease in $I_{\kappa} \mathrm{B} \alpha$ level (Figure 3c). Taken
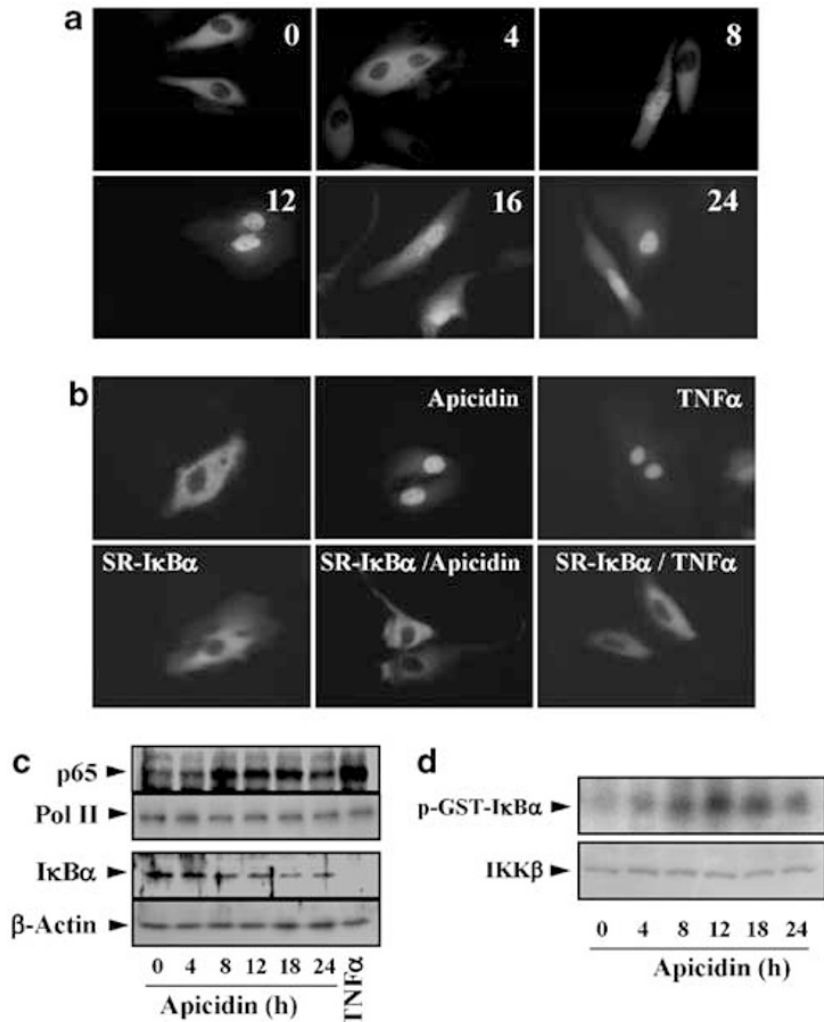

Figure 3 Apicidin promotes nuclear translocation of NF- $\kappa$ B. (a) HeLa cells were transfected with GFP-p65 expression plasmid DNA $(0.5 \mu \mathrm{g})$ for $48 \mathrm{~h}$ and were incubated with $1 \mu \mathrm{M}$ apicidin for the indicated times. Subcellular localization of GFP-p65 was measured using fluorescence microscope. Results were derived from inspection of at least 50 transfected cells present in multiple microscopic fields. (b) HeLa cells were cotransfected with GFP-p65 expression plasmid DNA $(0.5 \mu \mathrm{g})$ together with or without SR-I $\kappa \mathrm{B} \alpha$. After $48 \mathrm{~h}$ of transfection, cells were additionally incubated for $24 \mathrm{~h}$ with $1 \mu \mathrm{M}$ apicidin or for $1 \mathrm{~h}$ with $10 \mathrm{ng} / \mathrm{ml} \mathrm{TNF} \alpha$. (c) After treatment of cells with $1 \mu \mathrm{M}$ apicidin for the indicated times or $10 \mathrm{ng} / \mathrm{ml}$ TNF $\alpha$ for $1 \mathrm{~h}$, nuclear fractions were prepared. The levels of p65 in nuclear compartments were immunoblotted with anti-p65 antibodies. Total amounts of $\mid \kappa \mathrm{B} \alpha$ were also analyzed in whole-cell lysates. (d) Following apicidin treatment for the indicated times, the kinase activity of IKK $\beta$ immunoprecipitates was measured using GST-I $\kappa \mathrm{B} \alpha$ protein as substrate in the presence of $\left[\gamma^{32} \mathrm{P}\right] \mathrm{ATP} /$ ATP

together, these findings indicate that $\mathrm{IKK}-\mathrm{I}_{\kappa} \mathrm{B} \alpha$ signaling pathway is required for nuclear translocation of p65 in mediating apicidin activation of NF- $\kappa$ B.

\section{NF- $\boldsymbol{\kappa}$ B-regulated gene expression by apicidin}

To examine the contribution of NF- $\kappa \mathrm{B}$ activation by apicidin to the change of endogenous NF- $\kappa$ B-regulated gene expression, endogenous IL-8 mRNA level was analyzed using reverse transcriptase-polymerase chain reaction (RT-PCR). Increase in IL-8 expression by apicidin is weakly detected at $4 \mathrm{~h}$, peaking at $12 \mathrm{~h}$, which is different from the fast kinetics of IL-8 induction by TNF $\alpha$, which peaks at $1 \mathrm{~h}$ post-treatment and is sustained up to $24 \mathrm{~h}$ (Figure $4 \mathrm{a}$ ). This differential kinetics of IL-8 transcription by apicidin is consistent with the findings, shown in Figures $1 \mathrm{a}$ and $3 \mathrm{a}$, that apicidin requires at least $8 \mathrm{~h}$ of incubation time to initiate NF- $\kappa \mathrm{B}$ activation and nuclear localization. To investigate whether the $I \mathrm{KK}-\mathrm{I}_{\kappa} \mathrm{B} \alpha$ signaling 
a

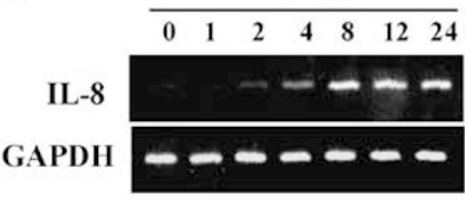

Apicidin

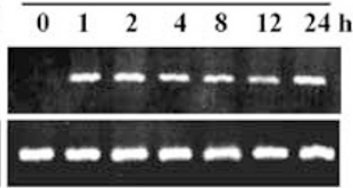

b

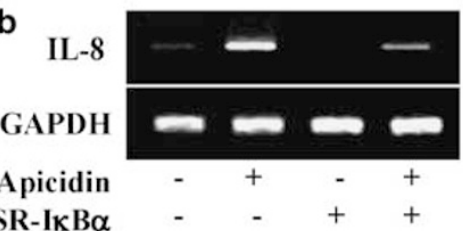

c
IL-8 promoter

IP; Ac-H3

Input

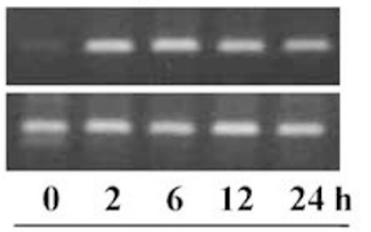

Apicidin

Figure 4 Apicidin induces NF- $\kappa$ B-dependent gene expression. (a) HeLa cells were treated with $1 \mu \mathrm{M}$ apicidin or $10 \mathrm{ng} / \mathrm{ml}$ TNF $\alpha$ for indicated time points, and IL-8 mRNA levels from total RNA were analyzed by RT-PCR as described in 'Materials and Methods'. (b) HeLa cells were transfected with SR-I $\mathrm{B} \alpha$ and then incubated with $1 \mu \mathrm{M}$ apicidin for $12 \mathrm{~h}$. (c) Soluble chromatin was immunoprecipitated with anti-acetylated histone $\mathrm{H} 3$ antibodies from HeLa cells cultured with or without $1 \mu \mathrm{M}$ apicidin for the indicated times. PCR primer for the promoter region of the IL-8 gene was used to amplify the DNA isolated from the immunoprecipitated chromatin, as described in 'Materials and Methods'

pathway is required for apicidin-induced IL-8 expression, we next examine changes in IL-8 mRNA level, using SR-I $\kappa \mathrm{B} \alpha$. As shown in Figure $4 \mathrm{~b}$, overexpression of SR-I $\kappa \mathrm{B} \alpha$ dramatically inhibits the increase of IL-8 mRNA level induced by apicidin, demonstrating that apicidin-induced IL-8 expression is mediated by the activation of NF- $\kappa \mathrm{B}$ signaling pathway. We also performed chromatin immunoprecipitation (ChIP) assay to determine the effect of apicidin on the acetylation of histone $\mathrm{H} 3$ associated with IL-8 gene promoter region, corresponding to NF- $\kappa$ B-binding site. As shown in Figure 4c, hyperacetylation of histone $\mathrm{H} 3$ by apicidin peaks within $2 \mathrm{~h}$ and is sustained up to $24 \mathrm{~h}$. Although histone hyperacetylation of IL-8 promoter region is observed within $2 \mathrm{~h}$ after apicidin treatment, mRNA of the IL-8, however, is not fully induced at this time point (Figure 4a). These results indicate that histone hyperacetylation of nucleosomes associated with IL-8 promoter region including NF- $\kappa$ B-binding site is not sufficient to induce the IL-8 expression in response to apicidin, and that activation of $\mathrm{NF}-\kappa \mathrm{B}$ signaling pathway is essential for full transcriptional activation of IL-8 gene.

\section{Requirement of de novo protein synthesis through Sp1 transcription factor for apicidin activation of $\mathrm{NF}-\boldsymbol{\kappa} \mathrm{B}$}

As we observed that apicidin required a prolonged period for NF- $\kappa$ B activation (Figures $2 \mathrm{a}$ and $4 \mathrm{a}$ ), we examine the contribution of de novo protein synthesis to the $\mathrm{NF}-\kappa \mathrm{B}$ activation, using a protein synthesis inhibitor cycloheximide $(\mathrm{CHX}, 50 \mu \mathrm{M})$. CHX pretreatment strongly abrogates the apicidin-induced nuclear translocation of p65 in GFP-p65overexpressed HeLa cells ( $94 \pm 4 \%$ (apicidin) versus $6 \pm 2 \%$ (CHX plus apicidin)). In contrast, $\mathrm{CHX}$ does not alter TNF $\alpha$ induced translocation (Figure 5). Therefore, our findings indicate that apicidin induction of p65 nuclear translocation through activation of $\mathrm{NF}-\kappa \mathrm{B}$ signaling pathway requires de novo protein synthesis.

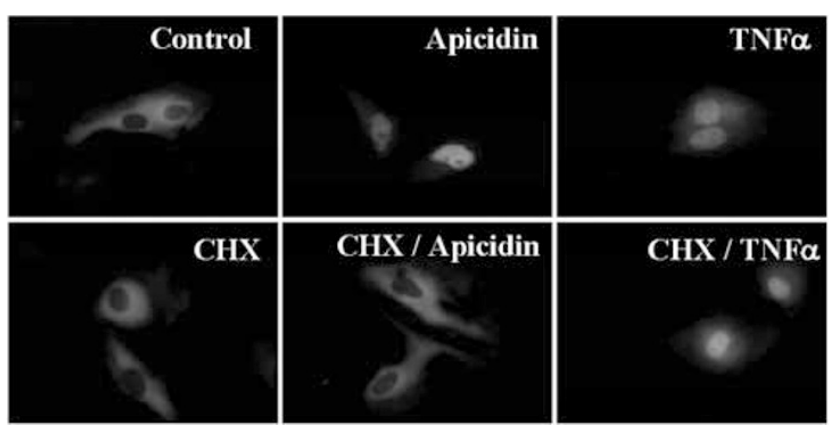

Figure 5 De novo protein synthesis is required for the apicidin-induced nuclear translocation of NF- $\kappa$ B. HeLa cells were transfected with GFP-p65 expression plasmid DNA $(0.5 \mu \mathrm{g})$ for $48 \mathrm{~h}$. After pretreatment of transfected cells with $\mathrm{CHX}$ $(50 \mu \mathrm{M})$ for $1 \mathrm{~h}$, the cells were further incubated for additional $24 \mathrm{~h}$ with $1 \mu \mathrm{M}$ apicidin or for an additional $1 \mathrm{~h}$ with $10 \mathrm{ng} / \mathrm{ml} \mathrm{TNF} \alpha$. Subcellular localization of GFP-p65 was measured using fluorescence microscope

Recently, accumulating evidences show that HDAC inhibitors such as apicidin and TSA could upregulate the transcription of a set of Sp1-dependent gene, including p21 WAF1/Cip1, cyclooxygenase-1, and telomerase reverse transcriptase. ${ }^{6,36,37}$ Therefore, we examine whether Sp1denendent genes upregulated by apicidin could be a possible mediator for NF- $\kappa$ B activation. As mithramycin (MTM) has been known as a chemical that modifies GC-rich regions of the DNA and blocks the binding of Sp1 family transcription factors, HeLa cells are pretreated with MTM. As shown in Figure $6 a$ and $b$, MTM pretreatment dramatically inhibits apicidin-induced expression of Sp1 reporter gene, but not PDBu-induced expression of NF- $\kappa \mathrm{B}$ reporter gene, thus indicating that MTM selectively inhibits the transcription of Sp1-dependent gene. Figure $6 \mathrm{c}$ and $\mathrm{d}$ show that MTM pretreatment significantly abrogates apicidin-induced NF- $\kappa \mathrm{B}$ activation and nuclear translocation ( $91 \pm 3 \%$ (apicidin) versus $4 \pm 1 \%$ (MTM plus apicidin)). These results suggest that apicidin activation of $\mathrm{NF}-\kappa \mathrm{B}$ requires an indirect involvement of Sp1. To further ascertain the requirement of 

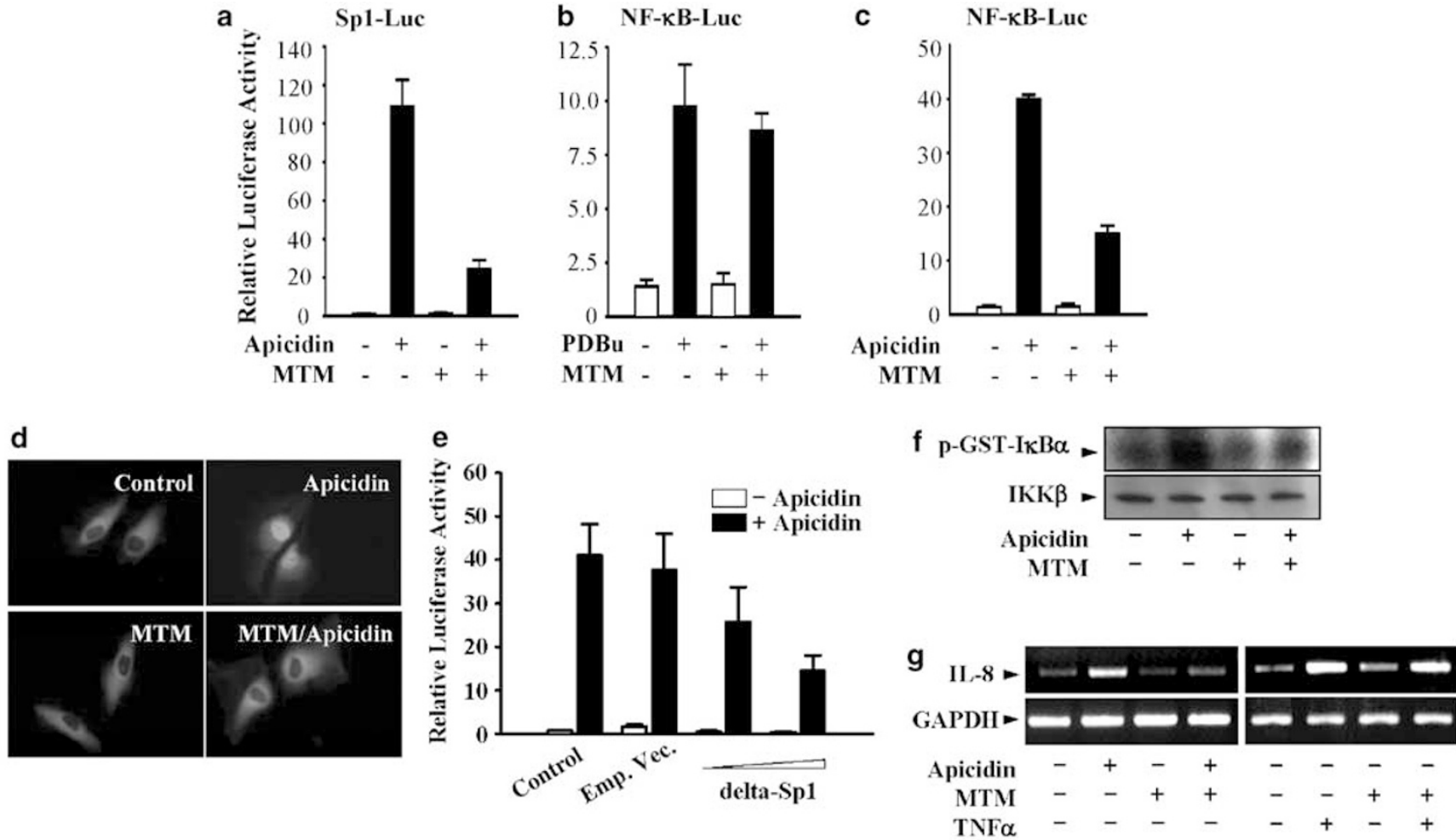

Figure 6 Apicidin-induced activation of NF- $\kappa$ B requires Sp1-dependent gene expression. (a) HeLa cells were transfected with Sp1 reporter plasmid DNA (1 $\mu \mathrm{g})$ for $24 \mathrm{~h}$. After pretreatment with $200 \mathrm{nM}$ MTM for $1 \mathrm{~h}$, the cells were incubated with $1 \mu \mathrm{M}$ apicidin for an additional $24 \mathrm{~h}$. Luciferase activity was determined as described in 'Materials and Methods'. After transfection of NF- $\kappa$ B reporter plasmid DNA $(1 \mu \mathrm{g})$ for $24 \mathrm{~h}$, cells that had been pretreated with $200 \mathrm{nM}$ MTM for $1 \mathrm{~h}$ were incubated with $50 \mathrm{nM}$ PDBu (b) or $1 \mu \mathrm{M}$ apicidin (c) for an additional $24 \mathrm{~h}$. (d) After transfection of GFP-p65 expression plasmid for $48 \mathrm{~h}$, cells were treated with $1 \mu \mathrm{M}$ apicidin for an additional $24 \mathrm{~h}$ in the presence of $200 \mathrm{nM}$ MTM. (e) HeLa cells were co-transfected with NF- $\kappa$ B reporter plasmid DNA (1 $\mu \mathrm{g}$ ) with or without dominant negative form of Sp1 (delta-Sp1; 1 or $5 \mu \mathrm{g}$ ) or control vector $(5 \mu \mathrm{g})$. After $24 \mathrm{~h}$ transfection, cells were further incubated for $24 \mathrm{~h}$, following $1 \mu \mathrm{M}$ apicidin treatment. (f) Cells were treated with $200 \mathrm{nM}$ MTM for $1 \mathrm{~h}$, followed by $1 \mu \mathrm{M}$ apicidin treatment for an additional $8 \mathrm{~h}$. The kinase activity of IKK $\beta$ immunoprecipitates was measured, as described in 'Materials and Methods'. (g) HeLa cells were treated with $1 \mu \mathrm{M}$ apicidin for $12 \mathrm{~h}$ or $10 \mathrm{ng} / \mathrm{ml} \mathrm{TNF} \alpha$ for $1 \mathrm{~h}$ in the presence of $200 \mathrm{nM}$ MTM, and IL-8 mRNA level from total RNA was analyzed

Sp1-dependent gene expression for apicidin-induced NF- $\kappa \mathrm{B}$ activation, the cells were transfected with dominant-negative mutant (delta-Sp1) of Sp1 transcription factor: delta-Sp1 contains DNA-binding domain of human Sp1, which confers sequence-specific DNA interactions, but not transactivation domain. Therefore, it can specifically inhibit the transcriptional activity of Sp1. Overexpression of delta-Sp1 significantly attenuates the apicidin-induced expression of NF- $\kappa$ B reporter gene (Figure 6e). Next, we determine whether these effects of Sp1 inhibition on the activation and nuclear translocation of NF- $\kappa \mathrm{B}$ are mediated by IKK signaling pathway. Figure $6 f$ shows that MTM treatment significantly decreases the apicidin-induced IKK activity. Finally, we examine the involvement of Sp1 in inducing NF- $\kappa$ B target gene IL-8 expression by apicidin or TNF $\alpha$. As shown in Figure $6 \mathrm{~g}$, the inhibition of Sp1 by MTM treatment does not affect TNF $\alpha$ induction of IL-8 transcription, indicating that transcription of IL- 8 by $\mathrm{TNF} \alpha$ is independent of Sp1 transcription factor. However, apicidinmediated induction of IL-8 transcription is markedly blocked by MTM (Figure 6f). Taken together, these results strongly indicate that $\mathrm{Sp} 1$ is involved in apicidin activation of $\mathrm{NF}-\kappa \mathrm{B}$ through $\mathrm{IKK}-\mathrm{I} \kappa \mathrm{B} \alpha$ signaling pathway, leading to induction of IL-8 gene expression.

\section{Involvement of NF- $\kappa \mathrm{B}$ signaling pathway in protection of HeLa cells from apicidin-induced apoptosis}

As NF- $\kappa \mathrm{B}$ has been established to provide an antiapoptotic role in various cancer cells, ${ }^{11,14}$ we examine the functional role of NF- $\kappa$ B activation by apicidin in apoptosis. By assaying Annexin $\mathrm{V}$ staining, poly (ADP-ribose) polymerase (PARP) cleavage, and caspase-3 activation, hall-marks of apoptosis, we first examine whether apicidin could induce apoptosis in HeLa cells. As shown in Figure 7a, apicidin treatment does not induce apoptosis in HeLa cells. On the other hand, Annexin Vpositive cells, cleavage of PARP, and caspase-3 activation dramatically occur in Jurkat $T$ cells treated with apicidin, indicating that apoptotic potential of apicidin is dependent on each cellular system. Therefore, we next examine whether the difference of apoptotic potential of apicidin between HeLa and Jurkat $\mathrm{T}$ cells is due to differential regulation of $\mathrm{NF}-\kappa \mathrm{B}$ : compared with marked induction of NF- $\kappa \mathrm{B}$ reporter activity in HeLa cells, apicidin causes a marginal increase of $\mathrm{NF}-\kappa \mathrm{B}$ in Jurkat $T$ cells which are sensitive to apoptotic potential of apicidin (Figure 7b). In parallel, treatment of HeLa cells with cytotoxic drug paclitaxel $(10 \mathrm{nM})$ leads to a dramatic increase 


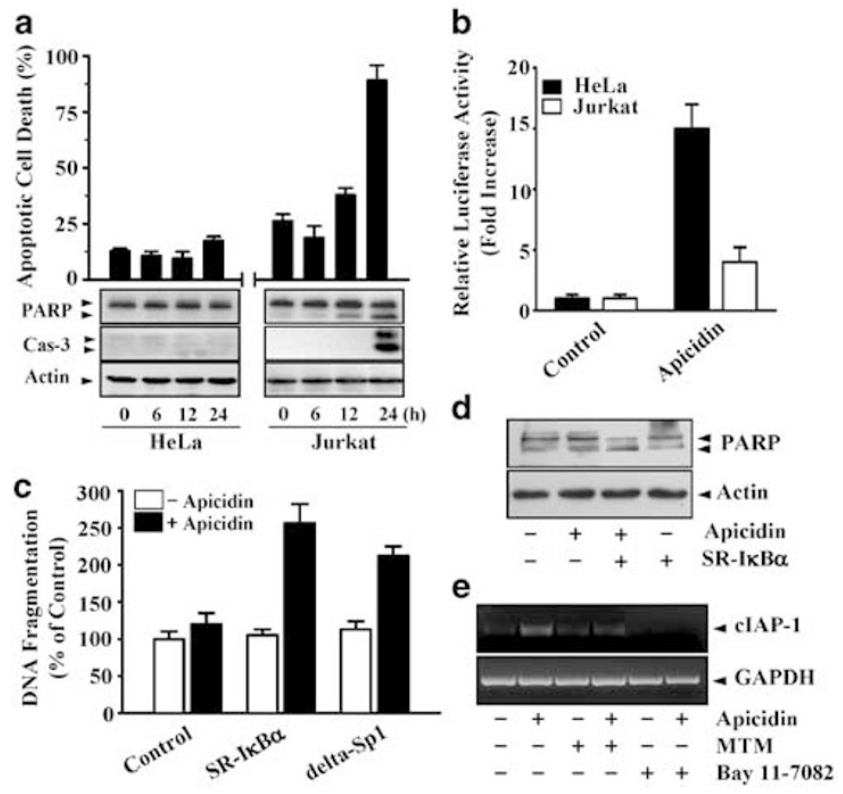

Figure 7 Loss of NF- $\kappa$ B by the expression of SR- $\mid \kappa B \alpha$ sensitizes HeLa cells to apicidin-induced apoptosis. (a) HeLa and Jurkat T cells were treated with $1 \mu \mathrm{M}$ apicidin for the indicated times. The cells were harvested and subsequently incubated with fluorescence-labeled Annexin $\mathrm{V}$ and subjected to analysis using flow cytometry as described in 'Materials and Methods'. The apoptotic cell death was evaluated as percentage of Annexin V-positive cells in total cells (mean \pm S.E.M., three independent experiments). PARP cleavage and caspase-3 (Cas-3) activation in cell lysates were examined by immunoblot analysis. (b) After transfection of cells with the NF- $\kappa$ B luciferase reporter plasmid DNA $(1 \mu \mathrm{g})$ for $24 \mathrm{~h}$, cells were additionally incubated for $24 \mathrm{~h}$, following $1 \mu \mathrm{M}$ apicidin treatment. Luciferase activity was determined as described in 'Materials and Methods'. Results represent mean \pm S.E.M. from three independent experiments. After transfection of HeLa cells with plasmids encoding SR-I $\kappa \mathrm{B} \alpha$ or delta-Sp1 for $24 \mathrm{~h}$, cells were further incubated for $24 \mathrm{~h}$, following $1 \mu \mathrm{M}$ apicidin treatment. Apoptosis was measured by the Cell Death Detection ELISA kit (c) or immunoblot analysis for PARP cleavage (d), as described in 'Materials and Methods'. (e) After pretreatment with MTM $(200 \mathrm{nM})$ or Bay 11-7082 $(10 \mu \mathrm{M})$ for $1 \mathrm{~h}$, cells were additionally incubated for $24 \mathrm{~h}$, following $1 \mu \mathrm{M}$ apicidin treatment. cIAP-1 mRNA levels from total RNA were analyzed by RT-PCR as described in 'Materials and Methods'

in apoptotic cell death, but not in NF- $\kappa$ B activation (data not shown). This finding suggests that ineffectiveness of apicidin to induce apoptosis in HeLa cells is most likely due to the activation of NF- $\kappa \mathrm{B}$, resulting in upregulation of cell survival signals. To further confirm the importance of NF- $\kappa$ B activation through IKK-I $\mathrm{I}_{\alpha} \alpha$ signaling pathway in HeLa cells that are resistant to apicidin-induced apoptosis, we analyze the effects of $\mathrm{SR}-\mathrm{I} \kappa \mathrm{B} \alpha$ on apoptosis following the addition of apicidin. As shown in Figure 7c, treatment of SR- $\left.\right|_{\kappa} \mathrm{B} \alpha$-overexpressed HeLa cells with apicidin markedly increases the sensitivity of the cells to apoptosis (approximately 2.5-fold increase, compared with that in control cells), and this finding is further confirmed by apicidin-induced PARP cleavage in SR-I $\mathrm{B} \alpha$ overexpressed HeLa cells (Figure 7d). In addition, apoptotic potential of apicidin is significantly increased in delta-Sp1transfected cells (Figure 7c). Next, we examine the expression of clAP-1, a well-characterized NF- $\kappa$ B downstream antiapoptotic molecule, and apicidin treatment is found to cause a dramatic increase in clAP-1 mRNA level, which is inhibited by pretreatment with either MTM or NF- $\kappa$ B inhibitor
Bay 11-7082 (Figure 7e). Collectively, these findings demonstrate that the protection of HeLa cells from apoptotic potential of apicidin is mediated by upregulation of NF- $\kappa \mathrm{B}$ activity.

\section{Discussion}

We have recently demonstrated the therapeutic potential of HDAC inhibitor apicidin for cancer treatment by elucidating the mechanism of how apicidin induces the cell cycle arrest at $G_{1}$ phase or apoptosis. ${ }^{2,3,6,7}$ However, the cellular response to apicidin appears to be dependent on each cellular system: difference in the apoptotic potential of apicidin has been observed, as evidenced by the fact that apicidin induces apoptosis in HL60 or Jurkat T cells, however, not in HeLa cells. In this study, we demonstrate that the unresponsiveness of HeLa cells to apoptosis following the inhibition of HDAC activity by apicidin is due to NF- $\kappa \mathrm{B}$ activation, which is mediated by IKK and $\mathrm{I} \kappa \mathrm{B} \alpha$ signaling pathway through Sp1dependent de novo protein synthesis. These findings strongly suggest that NF- $\kappa$ B activation is responsible for the differential responses of cells to apicidin.

Activation and nuclear translocation of $\mathrm{NF}-\kappa \mathrm{B}$ as an antiapoptotic transcription factor have been shown to be regulated by interactions of $\mathrm{NF}-\kappa \mathrm{B}$ with $\mathrm{I} \kappa \mathrm{B}$ protein. Recent study demonstrates that the $\mathrm{p} 65$ transported into the nucleus is subjected to inducible acetylation by $\mathrm{p} 300 / \mathrm{CBP}$, leading to its activation. ${ }^{10}$ The acetylated $p 65$ is subsequently deacetylated through a specific interaction with HDAC3, and this deacetylation reaction promotes effective binding to $\mathrm{I}_{\kappa} \mathrm{B} \alpha$, in turn leading to $\mathrm{I}_{\kappa} \mathrm{B} \alpha$-dependent nuclear export of the complex. In addition, it has also been reported that the association of $\mathrm{NF}-\kappa \mathrm{B}$ with the HDAC1 and HDAC2 corepressor proteins represses the expression of NF- $\kappa$ B-regulated genes. ${ }^{30}$ These results suggest that HDACs act as an intranuclear molecular switch that controls the duration of the NF- $\kappa$ B transcriptional response and contributes to the replenishment of the depleted cytoplasmic pool of latent NF- $\kappa \mathrm{B}-\mathrm{I}_{\kappa} \mathrm{B} \alpha$ complexes. Indeed, inhibition of HDAC activity by TSA has been shown to potentiate the transcriptional activity of $\mathrm{NF}-\kappa \mathrm{B}$ induced by TNF $\alpha .{ }^{10}$ However, in our experimental conditions, HDAC inhibitor apicidin alone is able to fully stimulate the transcriptional activity of NF- $\kappa \mathrm{B}$ in the absence of TNF $\alpha$ (Figures 1, 2 and 3 ), indicating that inhibition of HDAC activity leads to an accumulation of NF- $\kappa \mathrm{B}$ in the nucleus through either direct acetylation of a small amount of $\mathrm{NF}-\kappa \mathrm{B}$ existing in the nucleus or its transport from the cytosol into the nucleus by $\mathrm{NF}-\kappa \mathrm{B}$ signaling pathway. Consistent with these results, overexpressed GFP-p65 in HeLa cells is translocated from the cytosol to the nucleus in response to apicidin treatment. Similarly, endogenous p65 in the nucleus is also increased in a time-dependent manner by apicidin treatment (Figure 3). The accumulation of NF- $\mathrm{B}$, however, appears to be due to the activation of NF- $\kappa \mathrm{B}$ signaling pathway rather than direct acetylation of p65 in the nucleus, because overexpression of SR- $I_{\kappa} \mathrm{B} \alpha$ blocks NF- $\kappa \mathrm{B}$ accumulation in the nucleus, as well as the transcriptional activity of NF- $\kappa \mathrm{B}$ (Figures 2 and 3 ). Furthermore, we fail to detect any increase of p65 acetylation in HeLa cells (data not shown). This notion could further be confirmed by the observations that apicidin treatment leads to 
the stimulation of endogenous $\operatorname{IKK} \beta$ activity, which is followed by a decrease in $\mathrm{I}_{\kappa} \mathrm{B} \alpha$ level, and that dominant-negative form of IKK $\beta$ inhibits the apicidin-induced transcriptional activity of $\mathrm{NF}-\kappa \mathrm{B}$ (Figure 2). In contrast to our observations, Mayo et al. ${ }^{11}$ suggest that the ability of HDAC inhibitors to increase $\mathrm{NF}-\kappa \mathrm{B}$ transcriptional activity in NSCLC cells is not associated with signaling events that stimulate nuclear translocation, but rather is due to the increased transactivation potential of the p65 subunit of NF- $\kappa$ B through Akt activation. In addition, it has more recently been reported that HDAC inhibitors promote the accumulation of acetylated p65 in the nucleus, leading to $\mathrm{NF}-\kappa \mathrm{B}$ activation. ${ }^{38-40}$ Although the reasons for these discrepancies are not presently clear, it is quite likely that each cell type may adopt different signaling pathways.

Protein acetylation reaction influences a variety of cellular processes, including transcriptional regulation through the recruitment of enzymes, HDACs, and HATs. The packaging of eukaryotic DNA into chromatin plays an active role in transcriptional regulation by interfering with the accessibility to the transcription factor. Acetylation of specific lysine residues within the amino-terminal tails of nucleosomal histones is generally linked to chromatin disruption and transcriptional activation of genes. Consistent with the role of histone acetylation in altering chromatin structure, the loss of HDAC activity by inhibitors results in change of gene expression. Therefore, the activation of NF- $\kappa \mathrm{B}$ signaling pathway by apicidin might be attributed to alteration of specific gene expression through chromatin remodeling. In fact, NF$\kappa \mathrm{B}$ activation by apicidin requires a little longer time than that by the $\mathrm{NF}-\kappa \mathrm{B}$ inducer PDBu or $\mathrm{TNF} \alpha$ (Figure 1), indicating existence of a time-requiring process such as de novo protein synthesis for the activation of $\mathrm{NF}-\kappa \mathrm{B}$ signaling pathway by apicidin. In support of this notion, $\mathrm{CHX}$ treatment interferes with the accumulation of $\mathrm{NF}-\kappa \mathrm{B}$ in the nucleus by apicidin (Figure 5). It has repeatedly been demonstrated that HDAC inhibitors, including apicidin and TSA, could upregulate the transcription of a set of Sp1-dependent genes such as p21 WAF1/Cip1 cyclooxygenase-1 and telomerase reverse transcriptase. $6,36,37$ These observations lead to the assumption that one of Sp1 target genes might be responsible for the activation of $\mathrm{NF}-\kappa \mathrm{B}$ signaling pathway by apicidin. The specific inhibition of Sp1 transcription factor, using a chemical inhibitor MTM and dominant-negative mutant form of Sp1 significantly inhibits the apicidin-induced increase of transcriptional activity and translocation of $\mathrm{NF}-\kappa \mathrm{B}$ (Figure 6). Furthermore, the inhibition of Sp1 leads to a decrease of apicidin-induced IKK activity, indicating the involvement of Sp1-dependent gene expression in NF- $\kappa$ B activation through $\mathrm{IKK}-\mathrm{I}_{\kappa} \mathrm{B} \alpha$ signaling pathway, although a specific protein required for the $N F-\kappa B$ activation cannot be identified in this study. However, inhibition of either $I K K-I_{\kappa} \mathrm{B} \alpha$ signaling pathway or Sp1 transcription factor does not lead to complete abrogation of NF- $\kappa \mathrm{B}$ activation (Figure $6 \mathrm{c}$ and e). Therefore, we cannot rule out the possibility that apicidin affects NF- $\kappa \mathrm{B}$ activity by directly modulating its acetylation status, although we fail to observe acetylation of p65 following apicidin treatment.

Recent evidence suggests that gene activation by HDAC inhibitors is due to their ability to induce histone hyperacetylation in its promoter region, leading to transcriptional activation by facilitating the binding of transcription factors to nucleoso- mal DNA. ${ }^{41}$ However, this notion has recently been challenged by other reports that the transcriptional activation by HDAC inhibitor might be mediated by a mechanism other than chromatin remodeling through histone hyperacetylation; that is, an association with protein kinase signaling pathways. ${ }^{6-8}$ Our data show that IL-8 mRNA is maximally induced by apicidin at about $8-12 \mathrm{~h}$ post-treatment and is sustained until $24 \mathrm{~h}$. However, histone $\mathrm{H} 3$ associated with promoter region of IL-8 gene is fully hyperacetylated within $2 \mathrm{~h}$ post-treatment with apicidin, when IL-8 mRNA is not yet fully induced, indicating that histone hyperacetylation of nucleosomes associated with the promoter region of IL-8 gene is not enough to induce the IL-8 expression in response to apicidin, and that the signal-mediated activation of NF- $\kappa \mathrm{B}$ is necessary for its full expression through sustaining hyperacetylation of histone H3. These results implicate that the activation of NF$\kappa \mathrm{B}$ signaling pathway may contribute to selective changes of less than $2 \%$ of expressed gene by HDAC inhibitors. ${ }^{4,5}$

The apoptotic potential of apicidin has been demonstrated in human acute promyeolcytic leukemia cells HL60, indicating a possible anticancer drug development. ${ }^{3}$ However, apicidin does not induce the apoptotic cell death of HeLa cells, although cell proliferation was significantly inhibited. ${ }^{2}$ This difference between cell lines might be due to the ability of cells to upregulate genes involved in growth control or apoptosis through the modifications of chromatin structure. NF- $\kappa$ B could be one of the plausible candidate molecules to govern a differential cellular response of apicidin to induce apoptosis, because $\mathrm{NF}-\kappa \mathrm{B}$ activation could stimulate cell survival signaling pathway through the expression of $\mathrm{NF}-\kappa \mathrm{B}$ target gene. ${ }^{14}$ Indeed, transcriptional activity of $\mathrm{NF}-\kappa \mathrm{B}$ is significantly upregulated in HeLa cells by apicidin, but not in Jurkat $\mathrm{T}$ cells (Figure $7 b$ ), and disruption of either $I K K-I_{\kappa} B \alpha$ signaling pathway or Sp1 in HeLa cells leads to an increase of apoptotic potential of apicidin as well as a decrease in expression of anti-apoptotic molecule clAP-1 (Figure 7c-e), thus demonstrating that the ability of HeLa cells to overcome apoptosis in response to apicidin is attributable to $\mathrm{NF}-\kappa \mathrm{B}$ activation through Sp1-dependent IKK-I $\kappa \mathrm{B} \alpha$ signaling pathway. This is further supported by the observation that ineffectiveness of HDAC inhibitors to induce apoptosis in NSCLC cells is associated with the NF- $\kappa$ B activation through Akt-dependent phosphorylation of p300. ${ }^{11}$

In conclusion, we demonstrate that the protection of HeLa cells from apoptosis in response to apicidin is due to NF- $\kappa \mathrm{B}$ activation, which is mediated by upregulation of $\mathrm{IKK}-\mathrm{I} \kappa \mathrm{B} \alpha$ signaling pathway through Sp1-dependent de novo protein synthesis, and that inhibition of both HDAC and NF- $\kappa$ B finally sensitizes HeLa cells to apoptosis. Our studies provide a new insight into molecular mechanisms by which HDAC inhibitors activate NF- $\kappa$ B-dependent cell survival, and further suggest that the inhibition of NF- $\kappa \mathrm{B}$ in combination with HDAC inhibition may provide a novel approach for the treatment of human cancers.

\section{Materials and Methods}

\section{Cell culture}

HeLa cell line, derived from human cervix cancer, was cultured in Dulbecco's modified Eagle's medium (DMEM; Gibco, Grand Island, NY, 
USA), supplemented with $10 \%$ fetal bovine serum (HyClone Laboratories, Logan, UT, USA) and 1\% penicillin/streptomycin (Gibco).

\section{Reagents}

Apicidin, cyclo( $\mathrm{N}$-O-methyl-L-tryptophanyl-L-isoleucinyl-D-pipecolinyl-L-2amino-8-oxodecanoyl), was prepared from Fusarium sp. (Strain KCTC 16677) according to the method previously described. ${ }^{42}$ MG132, PDBu, CHX, BAY 11-7082, and TNF $\alpha$ were obtained from Calbiochem (La Jolla, CA, USA), and MTM was from BioMol (Plymouth Meeting, PA, USA).

\section{Plasmid constructs and antibodies}

Expression plasmids for $\mathrm{p} 65, \mathrm{I} \kappa \mathrm{B} \alpha$, dn-IKK $\alpha$, dn-IKK $\beta$, and GFP-p65 were provided by W C Greene (Department of Microbiology and Immunology, University of California, San Francisco, CA, USA). Antibodies for p65, $I_{\kappa} \mathrm{B} \alpha$, PARP, $\mid \mathrm{KK} \beta$, and actin were obtained from Santa Cruz Biotechnology (Santa Cruz, CA, USA), and antibody for cleaved active caspase-3 was from Cell Signaling Technology (Beverly, MA, USA).

\section{Luciferase reporter gene assay}

HeLa cells were seeded into either 6- or 24-well plates and cultured for $24 \mathrm{~h}$ in DMEM-10\%FBS before transfection. NF- $\kappa$ B-luciferase reporter plasmid DNA ( $1 \mu \mathrm{g}$, Stratagene, La Jolla, CA, USA) was transfected with expression plasmids encoding various genes for $24 \mathrm{~h}$, using ProFection transfection reagent (Promega, Madison, WI, USA). After transfection, the media were freshly replaced and incubated with or without various stimuli for the time indicated. The luciferase activities of the cell lysates were measured according to the manufacturer's instructions (Promega). Relative luciferase activity was normalized by total protein content of extract or cotransfection of Renilla luciferase reporter plasmids.

\section{Apoptosis assays}

After treatment of cells with apicidin for the indicated times, cells were harvested, and the extent of apoptosis was determined by flow cytometric analysis using Annexin-V-FITC apoptosis detection kit (BD Biosciences, San Diego, CA, USA), immunoblot analysis against activated caspase-3 and PARP cleavage, or DNA fragmentation assay using the Cell Death Detection ELISA Plus kit (Roche Applied Science, Indianapolis, IN, USA) according to the descriptions of the manufacturer.

\section{Immunoblotting}

Cell lysates were boiled in Laemmli sample buffer for $3 \mathrm{~min}$, and $30 \mu \mathrm{g}$ of each protein were subjected to SDS-polyacrylamide gel electrophoresis (PAGE). Proteins were transferred to polyvinylidene difluoride membranes, and the membranes were blocked for $30 \mathrm{~min}$ in Tris-buffered saline containing $0.1 \%$ Tween 20 and $5 \%$ (w/v) dry skim milk powder, and incubated overnight with primary antibodies. The membranes were then washed with TBS-0.1\% Tween 20 and incubated for $1 \mathrm{~h}$ with a secondary antibody, and were visualized with an enhanced chemiluminescence detection kit (Amersham Life Sciences, IL, USA).

\section{Fluorescence studies}

For localization of p65, HeLa cells were transfected with GFP-p65 alone or co-transfected with GFP-p65 and SR-I $\kappa \mathrm{B} \alpha$ for $48 \mathrm{~h}$, and followed by apicidin treatment for the indicated times. In some experiments, the cells were treated with apicidin for $18-24 \mathrm{~h}$ in the presence of $\mathrm{CHX}$ or MTM. Samples were viewed using a fluorescence microscope (Olympus IX70). A minimum of 50 cells were scored for quantification, and the results are expressed as the percentage of cells showing GFP-p65 nuclear translocation over control cells (GFP-p65-expressing cells).

\section{Subcellular fractionation}

Nuclear and cytoplasmic fractions were prepared from HeLa cells, using NE-PER nuclear and cytoplasmic extraction reagents (Pierce Biotechnology, Rockford, IL, USA) by following the manufacturer's instructions.

\section{In vitro I $k \mathrm{~B}$ kinase assays}

For $l_{\kappa} \mathrm{B}$ kinase assays, anti-IKK $\beta$ immunoprecipitates were rinsed two times with lysis buffer ${ }^{7}$ and once with kinase buffer $(20 \mathrm{mM}$ Tris- $\mathrm{HCl}, \mathrm{pH}$ 7.4, $10 \mathrm{mM} \mathrm{MgCl}_{2}, 2 \mathrm{mM} \mathrm{MnCl}, 1 \mathrm{mM}$ DTT, $25 \mathrm{mM} \mathrm{NaF}$, and $1 \mathrm{mM}$ sodium orthovanadate). The precipitates were resuspended in $40 \mu \mathrm{l}$ of kinase buffer containing $1 \mu \mathrm{g}$ of GST protein fused to amino acids 1-317 of $\mathrm{I} \kappa \mathrm{B} \alpha$ (Santa Cruz Biotechnology), $100 \mu \mathrm{M}$ ATP, and $10 \mu \mathrm{Ci}$ of $\left[\gamma^{32}\right.$ P]ATP (Amersham Biosciences, $3000 \mathrm{Ci} / \mathrm{mmol}$ ) and incubated for $20 \mathrm{~min}$ at $30^{\circ} \mathrm{C}$. The reaction was terminated with $10 \mu \mathrm{l}$ of $5 \times$ SDSsample loading buffer, boiled for $5 \mathrm{~min}$, and resolved by SDS-PAGE. Phosphorylation of substrate was visualized by autoradiography.

\section{Reverse transcriptase-polymerase chain reaction}

Total RNA was extracted using $\mathrm{TRI}_{\mathrm{zoL}}$ reagent (Invitrogen, Carlsbad, CA, USA). Integrity of RNA was checked by agarose gel electrophoresis and ethidium bromide staining. One microgram of RNA was used as a template for each RT-mediated PCR by using RNA PCR kit (Perkin Elmer, Wellesley, MA, USA). The primer sets for IL-8 were $5^{\prime}$-ATGACTTCCAAGCTGG CCGTGGCT-3' and 5'-TCTCAGCCCTCTTCAAAAACTTCTC- $3^{\prime}$; and the primer sets for CIAP-1 were $5^{\prime}$-TGAACTTGTCGACGATAGGTGTAG-3' and $5^{\prime}$-GTTGCTAGGATTTTTCTCTGAACTATC-3'.

\section{Chromatin immunoprecipitation}

ChIP assays were performed using the Acetyl-Histone H3 Immunoprecipitation Assay kit (Upstate Biotechnology, Charlottesville, VA, USA), according to the manufacturer's instructions. Chromatin from $1 \times 10^{6}$ HeLa cells sheared by a sonicator was precleared with salmon-sperm DNA-saturated protein $\mathrm{G}$ sepharose, and then precipitated by acetylated histone H3 antibody. Samples were analyzed by PCR using ExTaq polymerase (Takara, Japan). The human IL-8 promoter region from -121 to +61 was amplified with the primer pair $5^{\prime}$-GGGCCATCAGTTGC AAATC-3' and 5'-TTCCTTCCGGTGGTTTCTTC-3'.

\section{Acknowledgements}

This work was supported by Grant no. R01-2002-000-00213-0 from the Basic Research Program of the Korea Science and Engineering Foundation and a grant from Biomedical Brain Research Center of the Korea Health 21 R\&D Project funded by the Ministry of Health \& Welfare, Republic of Korea. (A040042).

\section{References}

1. Marks PA, Richon VM, Breslow R and Rifkind RA (2001) Histone deacetylase inhibitors as new cancer drugs. Curr. Opin. Oncol. 13: 477-483. 
2. Han JW, Ahn SH, Park SH, Wang SY, Bae GU, Seo DW, Kwon HK, Hong S, Lee HY, Lee YW and Lee HW (2000) Apicidin, a histone deacetylase inhibitor, inhibits proliferation of tumor cells via induction of $\mathrm{p} 21^{\text {WAF1/Cip1 }}$ and gelsolin. Cancer Res. 60: 6068-6074.

3. Kwon SH, Ahn SH, Kim YK, Bae GU, Yoon JW, Hong S, Lee HY, Lee YW, Lee HW and Han JW (2002) Apicidin, a histone deacetylase inhibitor, induces apoptosis and Fas/Fas ligand expression in human acute promyelocytic leukemia cells. J. Biol. Chem. 277: 2073-2080.

4. Marks PA, Richon VM and Rifkind RA (2000) Histone deacetylase inhibitors: inducers of differentiation or apoptosis of transformed cells. J. Natl. Cancer Inst. 92: 1210-1216.

5. Van Lint C, Emiliani S and Verdin E (1996) The expression of a small fraction of cellular genes is changed in response to histone hyperacetylation. Gene Expr 5: 245-253.

6. Han JW, Ahn SH, Kim YK, Bae GU, Yoon JW, Hong S, Lee HY, Lee YW and Lee HW (2001) Activation of p21 WAF1/Cip1 transcription through Sp1 Sites by histone deacetylase inhibitor apicidin: involvement of protein kinase C. J. Biol. Chem. 276: 42084-42090.

7. Kim YK, Han JW, Woo YN, Chun JK, Yoo JY, Cho EJ, Hong S, Lee HY, Lee YW and Lee HW (2003) Expression of p21 WAF1/Cip1 through Sp1 sites by histone deacetylase inhibitor apicidin requires $\mathrm{PI}$ 3-kinase-PKCesignaling pathway. Oncogene 22: 6023-6031.

8. Kobayashi H, Tan EM and Fleming SE (2004) Acetylation of histones associated with the p21 ${ }^{\text {WAF1/CIP1 }}$ gene by butyrate is not sufficient for p21 WAF1/ ClP1 gene transcription in human colorectal adenocarcinoma cells. Int. J. Cancer 109: 207-213

9. Xu Y (2003) Regulation of p53 responses by post-translational modifications. Cell Death Differ. 10: 400-403.

10. Chen L, Fischle W, Verdin E and Greene WC (2001) Duration of nuclear NF- $\kappa B$ action regulated by reversible acetylation. Science 293: 1653-1657.

11. Mayo MW, Denlinger CE, Broad RM, Yeung F, Reilly ET, Shi Y and Jones DR (2003) Ineffectiveness of histone deacetylase inhibitors to induce apoptosis involves the transcriptional activation of NF- $\kappa \mathrm{B}$ through the Akt pathway. J. Biol. Chem. 278: 18980-18989.

12. Baldwin Jr AS (1996) The NF- $\kappa \mathrm{B}$ and $\mathrm{I}_{\kappa} \mathrm{B}$ proteins: new discoveries and insights. Annu. Rev. Immunol. 14: 649-683.

13. Ghosh S, May MJ and Kopp EB (1998) NF- $\kappa B$ and Rel proteins: evolutionarily conserved mediators of immune responses. Annu. Rev. Immunol. 16: 225-260.

14. Tang G, Minemoto Y, Dibling B, Purcell NH, Li Z, Karin M and Lin A (2001) Inhibition of JNK activation through NF- $\kappa$ B target genes. Nature 414: 313-317.

15. Finco TS, Beg AA and Baldwin Jr AS (1994) Inducible phosphorylation of $I_{\kappa} \mathrm{B} \alpha$ is not sufficient for its dissociation from NF- $\kappa B$ and is inhibited by protease inhibitors. Proc. Natl. Acad. Sci. USA 91: 11884-11888.

16. Verma IM, Stevenson JK, Schwarz EM, Van Antwerp D and Miyamoto S (1995) Rel/NF- $\kappa \mathrm{B} / \mathrm{l}_{\kappa} \mathrm{B}$ family: intimate tales of association and dissociation. Genes Dev. 9: 2723-2735

17. Carlotti F, Dower SK and Qwarnstrom EE (2000) Dynamic shuttling of nuclear factor kappa $B$ between the nucleus and cytoplasm as a consequence of inhibitor dissociation. J. Biol. Chem. 275: 41028-41034.

18. Huang TT, Kudo N, Yoshida M and Miyamoto S (2000) A nuclear export signal in the $\mathrm{N}$-terminal regulatory domain of $I_{\kappa} \mathrm{B} \alpha$ controls cytoplasmic localization of inactive NF- $\kappa \mathrm{B} / \mathrm{l}_{\kappa} \mathrm{B} \alpha$ complexes. Proc. Natl. Acad. Sci. USA 97: 1014-1019.

19. DiDonato JA, Hayakawa M, Rothwarf DM, Zandi E and Karin M (1997) A cytokine-responsive $I_{\kappa} B$ kinase that activates the transcription factor NF- $\kappa$ B. Nature 388: 548-554

20. Mercurio F, Zhu H, Murray BW, Shevchenko A, Bennett BL, Li J, Young DB, Barbosa M, Mann M, Manning A and Rao A (1997) IKK-1 and IKK-2: cytokineactivated $I_{\kappa} B$ kinases essential for NF- $\kappa B$ activation. Science 278: 860-866.

21. Regnier CH, Song HY, Gao X, Goeddel DV, Cao Z and Rothe M (1997) Identification and characterization of an $1 \kappa B$ kinase. Cell 90: 373-383.

22. Zandi E, Rothwarf DM, Delhase M, Hayakawa M and Karin M (1997) The $I_{\kappa} B$ kinase complex (IKK) contains two kinase subunits, IKK $\alpha$ and IKK $\beta$, necessary for $I_{\kappa} \mathrm{B}$ phosphorylation and NF- $\kappa \mathrm{B}$ activation. Cell $91: 243-252$.

23. Finco TS and Baldwin AS (1995) Mechanistic aspects of NF- $\kappa$ B regulation: the emerging role of phosphorylation and proteolysis. Immunity 3: 263-272.
24. Gerritsen ME, Williams AJ, Neish AS, Moore S, Shi Y and Collins T (1997) CREB-binding protein/p300 are transcriptional coactivators of p65. Proc. Natl. Acad. Sci. USA 94: 2927-2932.

25. Perkins ND, Felzien LK, Betts JC, Leung K, Beach DH and Nabel GJ (1997) Regulation of NF- $\kappa$ B by cyclin-dependent kinases associated with the p300 coactivator. Science 275: 523-527.

26. Zhong H, Voll RE and Ghosh S (1998) Phosphorylation of NF- $\kappa$ B p65 by PKA stimulates transcriptional activity by promoting a novel bivalent interaction with the coactivator CBP/p300. Mol. Cell 1: 661-671.

27. Na SY, Lee SK, Han SJ, Choi HS, Im SY and Lee JW (1998) Steroid receptor coactivator- 1 interacts with the p50 subunit and coactivates nuclear factorkappaB-mediated transactivations. J. Biol. Chem. 273: 10831-10834.

28. Sheppard KA, Phelps KM, Williams AJ, Thanos D, Glass CK, Rosenfeld MG, Gerritsen ME and Collins T (1998) Nuclear integration of glucocorticoid receptor and nuclear factor-kappaB signaling by CREB-binding protein and steroid receptor coactivator-1. J. Biol. Chem. 273: 29291-29294.

29. Sheppard KA, Rose DW, Haque ZK, Kurokawa R, Mclnerney E, Westin S, Thanos D, Rosenfeld MG, Glass CK and Collins T (1999) Transcriptional activation by NF- $\kappa \mathrm{B}$ requires multiple coactivators. Mol. Cell. Biol. 19: 6367-6378.

30. Ashburner BP, Westerheide SD and Baldwin Jr AS (2001) The p65 (RelA) subunit of NF- $\kappa B$ interacts with the histone deacetylase (HDAC) corepressors HDAC1 and HDAC2 to negatively regulate gene expression. Mol. Cell. Biol. 21: 7065-7077.

31. Baek SH, Ohgi KA, Rose DW, Koo EH, Glass CK and Rosenfeld MG (2002) Exchange of $\mathrm{N}-\mathrm{CoR}$ corepressor and Tip60 coactivator complexes links gene expression by NF- $\kappa$ B and beta-amyloid precursor protein. Cell 110: 55-67.

32. Zhong H, May MJ, Jimi E and Ghosh S (2002) The phosphorylation status of nuclear NF- $\kappa$ B determines its association with CBP/p300 or HDAC-1. Mol. Cell 9: 625-636.

33. Yamaoka S, Courtois G, Bessia C, Whiteside ST, Weil R, Agou F, Kirk HE, Kay RJ and Israel A (1998) Complementation cloning of NEMO, a component of the I $\kappa$ B kinase complex essential for NF- $\kappa$ B activation. Cell 93: 1231-1240.

34. Hu Y, Baud V, Delhase M, Zhang P, Deerinck T, Ellisman M, Johnson R and Karin M (1999) Abnormal morphogenesis but intact IKK activation in mice lacking the IKK $\alpha$ subunit of $I_{\kappa} B$ kinase. Science 284: 316-320.

35. Li ZW, Chu W, Hu Y, Delhase M, Deerinck T, Ellisman M, Johnson R and Karin $M(1999)$ The IKK $\beta$ subunit of $I_{\kappa} B$ kinase (IKK) is essential for nuclear factor kappaB activation and prevention of apoptosis. J. Exp. Med. 189: 1839-1845.

36. Taniura S, Kamitani H, Watanabe T and Eling TE (2002) Transcriptional regulation of cyclooxygenase-1 by histone deacetylase inhibitors in normal human astrocyte cells. J. Biol. Chem. 277: 16823-16830

37. Hou M, Wang X, Popov N, Zhang A, Zhao X, Zhou R, Zetterberg A, Bjorkholm M, Henriksson M, Gruber A and Xu D (2002) The histone deacetylase inhibitor trichostatin A derepresses the telomerase reverse transcriptase (hTERT) gene in human cells. Exp. Cell Res. 274: 25-34.

38. Dai Y, Rahmani M, Dent P and Grant S (2005) Blockade of histone deacetylase inhibitor-induced RelA/p65 acetylation and NF- $\kappa$ B activation potentiates apoptosis in leukemia cells through a process mediated by oxidative damage, XIAP downregulation, and c-Jun N-terminal kinase 1 activation. Mol. Cell. Biol. 25: 5429-5444.

39. Adam E, Quivy V, Bex F, Chariot A, Collette $Y$, Vanhulle $C$, Schoonbroodt $S$, Goffin V, Nguyen TL, Gloire G, Carrard G, Friguet B, De Launoit Y, Burny A, Bours V, Piette J and Van Lint C (2003) Potentiation of tumor necrosis factorinduced NF- $\kappa$ B activation by deacetylase inhibitors is associated with a delayed cytoplasmic reappearance of $\mid \kappa \mathrm{B} \alpha$. Mol. Cell. Biol. 23: 6200-6209.

40. Chen LF and Greene WC (2003) Regulation of distinct biological activities of the NF- $\kappa$ B transcription factor complex by acetylation. J. Mol. Med. 81: 549-557.

41. Richon VM, Sandhoff TW, Rifkind RA and Marks PA (2000) Histone deacetylase inhibitor selectively induces p21 ${ }^{\text {WAF1 }}$ expression and geneassociated histone acetylation. Proc. Natl. Acad. Sci. USA 97: 10014-10019.

42. Park JS, Lee KR, Kim JC, Lim SH, Seo JA and Lee YW (1999) A hemorrhagic factor (apicidin) produced by toxic Fusarium isolates from soybean seeds. Appl. Environ. Microbiol. 65: 126-130. 